\title{
2. Putting Public Space into Perspective in the Performing Arts and Street Arts
}

\author{
Emmanuel Wallon \\ doi.org/10.3280/oa-637-2
}

According to its champions, theatre is political in essence, because it is intrinsically linked to public affairs, and it is social by birth because it is related to the city and it willingly engages its audiences by challenging the authorities. Is that so? Methodically discussed (Hamidi-Kim, 2013) or vigorously denounced (Neveux, 2019), these stereotypes deserve to be examined. Before celebrating its civic virtues, let us measure the place that theatre actually occupies in the city in three dimensions (or even four if we take into account the variable of time), or at least consider the vision it proposes of public space. We understand public space as the place of deliberation, but also as the space of conflict, in its almost unlimited urban development (Paquot, 2006), but also in the functioning of a communication which claims to be based on a pragmatic reason (Habermas, 1981).

The legend of a fundamentally civic art starts from a false analogy between the theatre and the agora, which is said to be the foundation of Athenian democracy. However, Clisthenes's reforms, begun in $508 \mathrm{BC}$ and reputed to have favoured the establishment of the rule of equality before the law (isonomia), delimited the districts of Athens with the primary aim of redefining citizenship on territorial rather than tribal bases; by doing so they also led to a functional and symbolic division of the urban plan, between the space for the representation of the world (mimesis) and the cathartic circulation of emotions on the one hand, and the space for political participation (politeia) on the other. The agora was located in a secular setting, below the sacred hill of the Acropolis, on the side of which the Theatre of Dionysus was situated. The confusion between these two "species of spaces», as Georges Perec would say, was nevertheless destined for long posterity. A retrospective and undoubtedly anachronistic conception of the Western Middle Ages supposed that the agora was created in the forecourt of cathedrals where the wagons of the mystery plays were set up, in the market squares where scaffolds were erected for public executions, if not within the framework of the fair where trestles were assembled for the farces. In the $19^{\text {th }}$ century, ruling classes voted for by progressively wider electoral bases consciously played on the similarities between the parliamentary hemicycle and the so-called "Italian- 
style" hall, as if political representation had to adopt the codes of theatrical representation in order to convince and seduce. In the following century, trade unions and parties who challenged the hegemony of the ruling classes and learned professions over the conduct of public affairs, set up the platforms for their meetings like open-air stages. Lastly, through a reversal of the direction of the transfer between models, which reveals the marginalisation of the dramatic rite in the society of instant communication, the theatre of the $21^{\text {st }}$ century sometimes borrows from the television studio, if not from digital networks, certain models of interaction with its assembly. The conviction to address the entire city through the tens or hundreds of spectators in front of whom the actors perform is therefore at the same time inspired by the history of the dramatic genre, encouraged by the parallelism of forms between the space of artistic representation and the space of political representation, reinforced by the centrality of the theatre building in the urban plan from the $16^{\text {th }}$ to the $19^{\text {th }}$ century, suggested by the symbolic transfers from one universe to another, and finally attested by the metaphorical use of the vocabulary of the spectacle in the electoral lexicon: public stage, coup de théâtre, spotlight, backstage...

If the discourse of the defenders of public theatre - an expression which, in the literal sense, is rather a pleonasm - readily refers to the Athenian origins of democracy, its genealogy weaves together several threads that do not stem from ancient Greece, but go back to the medieval mysteries, the farces played in fairground booths, the dramas and comedies of the court theatre, the inventions of the $18^{\text {th }}$ century théatres de société, the entertainment of the boulevard theatres, the audacity of the art theatre and the principles of the so-called popular theatre. Along the way, the pioneers of the latter also mixed with the supporters of militant theatre, be it associative or trade-unionist, secular or confessional, socialist, communist or anarchist. The formulas of this combination varied from one country to another, but the phenomenon spread throughout Europe.

\section{From the Fourth to the Fifth Wall}

In the subsidised sector as it gradually emerged from the rubble of World War II, the space offered for the consideration of spectators included three inseparable components of the theatrical ceremony: the stage, area devoted to fiction, reserved for the actors; the stalls/auditorium, dedicated to the perception of the show offered on the stage, but also to self-perception; and finally the hall and its annexes (porch/steps, entrance, counters, stairs, galleries, foyer, bar, cloakroom, toilets), all forming together a forum open to social life. This theatre declared itself a public service (Vilar, 1975). As vibrant as Jean Vilar's words were, as resolute as his action and the initiatives 
of his companions in "dramatic decentralisation" were, in France as elsewhere, the ideal of a theatre that was both national and popular came up, nevertheless, against the barriers that hindered attendance by the less fortunate and, above all, less educated classes. In three stages and three movements - the Odéon in May, Villeurbanne in June, Avignon in July (Rauch, 2008; Guénoun, 2012) - the year 1968 heralded the end of the republican illusion of equality achieved in communion with the masterpieces of the repertoire.

In order to elevate the spectators present (privileged minority) to the dignity of emissaries of the absent people (hidden majority), in other words to make the public the agent and witness of the "non-public" (Jeanson, 1968; Saez, 2015), methods fluctuate from one decade to the next, from one institution to another. While the animators or mediators try to broaden, rejuvenate and diversify the audience through cultural actions, with a view to democratisation, the directors try out different forms of address to the spectators in order to draw them out of their supposed comfort: verbal or physical confrontation, questioning from balconies, inviting participation, attempts at inclusion.

The breaking of the fourth wall, if it ever existed, in other words the transgression of the semiotic separation between the stage and the auditorium, between the place of the virtual and the place of the real, considered harmful to the elevation of thought by certain media theorists (Debray, 2005; Bougnoux, 2006), is severely judged by art historians and critics. Thus Michael Fried, speaking of minimalist painting in a 1967 essay, felt that a certain theatricality brings the inherent properties of the authentic modern work of art down to everyone's viewing experience (Fried, 1998). It is, however, a leitmotif of the saga of European staging in the $20^{\text {th }}$ century, from Adolphe Appia, Edward Gordon Craig, Jacques Copeau and Vsevolod Meyerhold, down to Giorgio Strehler, Antoine Vitez, Luca Ronconi, Ariane Mnouchkine, Klaus Michael Grüber, Patrice Chéreau or Romeo Castellucci. Even in the absence of direct spectators' involvement, the inclusion of the spectator in the performance apparatus constitutes in itself a petition of principle on the part of playwrights who, according to Armand Gatti, are in breach of the conventions of the established social order. This is for example what he said of Erwin Piscator and Bertolt Brecht, and more generally of German and Russian theatres of the inter-war period, paying tribute to the apology of Athens at the same time («normal theatre, as the Greeks did!») during a course on Street Theatre/Committed Theatre, given in 1972 at the Freie Universität Berlin:

All those who were in the hall in those years had personally experienced the era of the revolution evoked by the shows, and it was their 
destiny that they saw before them. The theatre had become a reality for them, it ceased to be like the theatre we were fighting against, that is to say, the stage against the auditorium, and it became a single meeting room, a single large battlefield, a single large event (Hocquard and Tanon, 2014, p. 59).

And Gatti took action in Berlin, occupying the street one evening with fireworks, climbing on the roof of a prison, working in the mining and industrial cities of Walloon Brabant, the suburbs of Lyon and a hundred other places until the age of ninety.

Around 1968, the theatrical convention wavered under the impetus of two combined but uncoordinated movements, one coming from within, the other from outside the dramatic institution (Wallon, 2018, p. 135-136).

Experiences of «emancipated performances», in other words, freed from submission to the dramatic text (Dort, 1988), but also freed from the shackles of frontality, are carried out within the institution without upsetting it. Others escape from it without necessarily opposing it. Some of the most beautiful theatrical adventures thus sparkled in the fringes at the beginning of the 1970s. The desire to get out of the palaces of traditional culture and go directly to meet the people where they lived, became stronger. North American companies have sown the seeds of this peaceful rebellion on European soil: the Teatro Campesino by Luis Valdez, the Bread and Puppet Theater by Peter Schumann, the Living Theater by Julian Beck and Judith Malina. In the same period, Dario Fo and Franca Rame roamed Italy from abandoned warehouses to school playgrounds, from occupied factories to private homes, with the Nuova Scena collective, and then without it. Augusto Boal, forced into exile by the Brazilian dictatorship in 1971, brought the theory and practice of Theatre of the Oppressed to the Old Continent (Boal, 1974).

Once the fourth wall that protected the representation had been knocked down (metaphorically), in Italy, France, Germany and Belgium, performers of all kinds began to break through the fifth, this invisible wall that was supposed to isolate fiction from the reality to which it referred and separate the theatre from the city. The development of so-called "street theatre" had only just begun. Since then, it has continued to explore the perspectives and blind spots of urban space.

This undeclared international movement, which is even less structured, but which has retained some of the maxims of the Lettrists and Situationists, treats «the street as the topos or commonplace of urbanity», as «the synecdoche of the entire city and as the metonymy of the people» (Wallon, 2018). Scende in piazza, it takes to the streets: it treads the pavement, 
certainly not to throw stones at the forces of law and order, or even to challenge the elected authorities, but to make fun of their rituals, to mobilise the laughter of the crowds against conventions and clichés. In doing so, it revives an imagery of the rebellious street that had been particularly popular in France since the Revolution, through the writings of Honoré de Balzac, Alexandre Dumas, Victor Hugo, Jules Vallès, Émile Zola, Hector Malot, Eugène Sue and many others. The street arts do not in any way raise the barricades that are so numerous in the history of the Parisian revolts, from 1789 to 1944, and from May 1968 to November 2018, when the gilets jaunes ploughed the Champs-Élysées. Nonetheless, they contribute to the preservation of a concept of public space that is deeply rooted in the collective memory, that of a sphere of direct expression.

\section{360 Degrees View}

In this sense, the city is a 360-degree theatre, in the words of Pino Simonelli (1948-1986), theatre critic and cultural animator in Casoria, taken up by one of his spokespersons in France, Michel Crespin (1940-2014), the founder in 1982 of Lieux Publics (Centre National de Création pour les Arts de la Rue, the national creation centre for street arts, now in Marseille) and of the Festival International des Arts de la Rue d'Aurillac in 1986. In his brilliant Portrait de l'artiste en saltimbanque (1970), Jean Starobinski, historian of literature and medicine, analysed the reasons why the figures of the acrobat, the horsewoman, the tightrope walker and the clown, symbols of the artist exposed to the peril of reality, haunted painting from Romanticism to Cubism, just as they lurked in the literature of the Belle Époque, before World War I. It remains to be explained how and why the «cogne-trottoirs ${ }^{3} »$ of street theatre - Michel Crespin's formula to indicate urban performers have inspired over the last forty years the outdoor productions of artists from all disciplines (circus artists, dancers, puppeteers, musicians, visual artists, videographers, fireworks experts), while the same artists were borrowing some of the street performers' ways of intervention in urban environments. This permeability between the various artistic fields is one of the characteristics of creation in the public space, as if the institutional and commercial logics that assign to each discipline its own domain, its rank, its shrines, its rituals, its clerics and its followers were diluted in the great flow of the city.

Breaking down the steps that animate this incessant exchange allows us to better grasp its meaning. First of all, it stems from social mobilisations: politicised artists have gone to meet employees in companies on strike,

\footnotetext{
${ }^{3}$ Translator's note: literally those who hit the pavements.
} 
immigrants in social centres and socio-cultural associations, schoolchildren in their playgrounds, students on their campuses, peasants in remote barns. Other artists animated the seasonal celebrations of left-wing or extreme leftwing newspapers, anti-nuclear or ecological gatherings whose regionalist spirit was often palpable. As has just been pointed out, relocation also stems from a movement of departure from the theatres, incapable, despite their efforts, of attracting members of the dominated classes to them. The show burst into premises that had not been designed for performance: back rooms of cafés, disused train stations, ruined factories, outdoors, supermarket car parks, etc. In these circumstances, theatres have regained a mobility that they had lost throughout their history, whether they went roaming, as companies revisited the tradition of fairground troupes, or wandering, as the show itself hit the streets, taking its audience with it.

This mobility soon contaminated the theatrical work of art as such, and the notion of «well-made play», theorised by Eugène Scribe in the middle of the $19^{\text {th }}$ century (Bara and Yon, 2016), gradually gave way to the onslaught of the work in progress, woven of improvisations, conducive to retouching, adjusting and reworking. The act often prevailed over words, and gesture over text, and they also seized the body of the actor, who in many cases assumed a plurality of roles, from author to stagehand, from set designer to performer.

Cultural policies have amplified this phenomenon since the 1980s. The State has contributed to this by granting its recognition to street arts companies, factories and festivals in the form of grants, commissions, labels, nominations. The local authorities have given them even more vigorous support through decentralisation. Their demand for local performances and festivals to celebrate "living together in the city" has led to an increase in the number of permanent structures and ephemeral events.

But every subsidy has its downside. What was the counterpart of national and local government aid? Gaudibert, former animator, curator and critic of modern art, follower of communist philosopher Louis Althusser, posed the question in these terms in the early 1970s in his book Action culturelle: intégration et/ou subversion (Gaudibert, 1972). For him, the function of the state cultural apparatus is to recycle artistic criticism into acceptance of the established order. Indeed, the dilemmas faced by creation in the public space will give food for thought to social theatre practitioners. Leaving the institutions does not automatically mean freeing oneself from power relationships and power logics. Artists, albeit freed from the rules and limits of the sessions between four walls, must arbitrate on a daily basis between their aspiration for political and aesthetic self-determination on the one hand, and the respect of the specifications expressly linked to their contracts, or at 
least the codes of conduct tacitly accepted in their area of intervention, on the other. The poetic insurrection they call for may ultimately prove to be nothing more than a mission of cultural mediation or social cure. Depending on the context, the same weapons of the imagination may be used to raise awareness of injustice or to provide harmless entertainment.

The French example seems quite revealing in this respect. In France, the structuring of the profession has undergone a process of legitimation during the 1990s and 2000s. Coming from the margins of the subsidised sector but grouped together in the same association - the Fédération Nationale des Arts de la Rue (national federation of street arts) born in September 1997, colloquially called Fédé, which acts as a think tank, network and union at the same time -, companies whose names resonate like a manifesto (Générik Vapeur, Royal de Luxe, Ilotopie, Oposito, Délices Dada, 26000 Couverts, Kumulus, Komplex Kapharnaüm and many more) have demanded public aid, obtained the creation of a resource centre financed by the Ministry of Culture (Hors Les Murs, whose resources were absorbed in 2016 by the multidisciplinary centre Artcena) and contributed to the cultural development of the territory by establishing their "workshops" in urban peripheries, as well as in rural areas. At the end of a long process of consultation with the supervisory authorities, an important stage of which was the Temps des Arts de la Rue, a three-year programme (2005-2007) to support this branch of the performing arts, several of them were elevated in 2017 by the State, the host municipalities and regions to the dignity of Centres Nationaux des Arts de la Rue et de l'Espace Public (CNAREP, national centres for the street arts and public space), of which there are fourteen today (including Lieux Publics, stakeholder of a vast Cité des Arts de la Rue in Marseille). All that was missing was an official training body to crown these schemes. This is the role of the Formation Avancée Itinérante pour les Arts de la Rue (FAI-AR, peripatetic advanced training for the street arts), also based in Marseille, whose first apprenticeship activities began in 2005 .

\section{The Transformation of Urban Space}

In presenting its Rue Libre (free street) programme to promote «freedom in the public space», the Fédé office declared on its website, in 2017, «to favour the festive and convivial agora and the joyful creative chaos against the temptation to withdraw into oneself». In fact, with four hundred members out of nearly a thousand artists and teams listed, relying on a tight network of some forty factories and around 250 festivals mainly or partly devoted to the street arts (including those of Aurillac, Chalon-sur-Saône, Châlons-enChampagne, Sotteville-lès-Rouen, Cognac and many others) (Wallon, 2016, p. 5), the «professionals of urban disorder», as they call themselves, have 
points of view - both literally and figuratively - to put forward on the issues of the urban world. The institutionalisation of this contestation undoubtedly erodes the critical edge of their discourse and the radicality of their works, but their dependence on public funds does not stifle their potential for making demands, nor their ability to probe the evils of the city. The aberrations of an urbanisation voracious for hectares of nature, the conversion of public living areas into commercial surfaces, the place of women in public life, the relegation of migrants to lawless areas, the generalised surveillance of neighbourhoods: these are all themes which their creations use as a pretext and from which they extract their materials.

In addition to trying to put the influence of public partners (ministries, local governments, social landlords, public developers, health authorities, etc.) into perspective, artists in urban spaces must meet the challenges linked to the transformation of their physical, economic and legal working environment, involving in particular the proliferation of safety regulations. The changes in the semiotic landscape are no less confusing for them. In three decades they have observed: the increased appropriation of theatrical techniques by protesters and demonstrators in their public actions and flash mobs; the growing sophistication of the dramaturgy and scenography of official ceremonies, the gesture of power being accompanied by a frantic recourse to storytelling and picture making orchestrated by communication advisers; the systematic aestheticisation of merchandise, through marketing strategies based on events; the dilution of the desire for discovery in the rising tide of performance production; and finally the metamorphosis of public space itself under the pressure of the mass media, programme industries and operators of the so-called "social" networks. This posthumous victory of Guy Debord's theses on the «society of the spectacle» leaves some people bewildered. While some look for remedies in hybrid realisations for fixed, mobile or device-assisted audiences, others focus above all on the participation, inclusion or immersion of the spectator. One example of this is the GK Collective (founded in 2009 by Hungarian Gabriella Cserháti), whose apparatus aims to intensify human relations in order to compete with the attraction of connected screens, in the hope of «creating another legitimacy for theatre in a society overloaded with generators of illusions» (GK Collective - Agence de Rencontre sans Risque, 2019).

How can these attempts to trace new perspectives in the public space, or to propose new perceptions of it, inform theatrical practices immersed in the multiple centres of social life? Drawing lessons applicable to as many diverse configurations as there are communities concerned would require a modicum of caution. However, the experiences projected in the streets have the same relevance as those that take place in enclosed spaces, they belong to the same 
time, characterised by an advanced stage of dissemination of the theatre. In search of the public legitimacy and social visibility that their regular audience is no longer able to provide alone, the best equipped and best located cultural establishments themselves deploy a large number of external interventions, amateur workshops, extramural activities: from artistic directors to staff «in charge of relations with the public», from permanent actors to guest companies, they make incursions into municipal buildings, parish halls, social centres, they set up projects with schools, colleges, high schools and universities, but also operate in local hospitals, prisons and retirement homes. Because it is intended to be fruitful, I have called this dispersion «swarming», to borrow the metaphor from Belgian playwright Maurice Maeterlinck's La vie des abeilles (Wallon, 2019).

The traditional divide between the inside and outside of the theatre therefore loses its relevance, while the gap between amateurs and professionals tends to narrow a little. Whatever the space in which it is practised, whether it is an enclosed stage, an open square or a living space, the theatre seeks above all to produce an intensification of presence, to stimulate a heightened awareness of the richness of the hic et nunc, to deepen the vertigo of a sensitive exchange that cannot be offered by the instant connections of digital communication networks. While yesterday's protest troupes sought to shake up the certainties of bourgeois society and challenge the conventions of its mimetic representation, in the face of the risk of dissociation experienced by communities torn apart by inequalities, many of today's artists, some out of conviction, others out of obligation, seem to take on an educational vocation and even accept a mission of "connection" or "reliance" - two words that in French originate from the $15^{\text {th }}$ century and may well be back in use again usually assigned to social workers. The «dramaturge» turns then into a «thaumaturge», as I argued in the article quoted.

If this hypothesis is confirmed, the elective shock that major works are reputed to provoke at the heart of the aesthetic experience would quietly give way to the primacy of the contagion of emotions. There would not be reason to rejoice nor to be offended, only to wonder. To what revelations can the circulation of affects lead? Under what conditions does the liberation of sensibility promote the emancipation of subjectivity? The answers to such questions will depend on the level of relevance and coherence of each project, but also on the degree of independence of the artists in relation to the commission (implicit or explicit) given to them, because it is ultimately on these criteria, more than on the context of their action, that their difference with mediators and social agents is marked.

One thing is certain: no strategy aimed at the empowerment of the subject is likely to succeed without the active, conscious, sensitive, critical 
involvement of those to whom the invitation to loosen the corset of alienation is addressed.

It is on this point, however, that a convergence is emerging between the approaches of the street arts and social theatre, which are so different in so many ways. On both sides, the spectator cannot be considered as the simple recipient of messages and images. The street arts claim to mobilise «spectactors», even if it means twisting the meaning Augusto Boal gave to this oxymoron in his forum theatre, because they entrust the audience with the right to interact with the actors, in addition to the responsibility of composing the setting and the moving scenery of the performance through their movements; social theatre encourages the members of the audience to become actors (simply) of their own lives, if only for a short time.

Do these poetic parentheses have a political impact beyond the circle of participants? The question is still pending, but the ancient requirement of theatre remains: to take place in order to allow the embodiment of public life. 